Article

\title{
Comparative Theology: Between Theology and Religious Studies
}

\section{Reinhold Bernhardt}

Chair of Systematic Theology/Dogmatics, Theological Faculty, University of Basel (CH), Heuberg 33, CH-4051 Basel, Switzerland; E-Mail: Reinhold.Bernhardt@unibas.ch; Tel.: +41-061-267-04-93

Received: 26 July 2012; in revised form: 10 October 2012 / Accepted: 12 October 2012 /

Published: 15 October 2012

\begin{abstract}
In the German-speaking academy there is a widespread rivalry between theology and religious studies. "Comparative Theology" provokes suspicions from both sides. This contribution first takes a look at the history of the rivalry, refers then to the criticism from both sides against "Comparative Theology" and suggests a way of positioning it between the two stools. It pleads for distinguishing between the levels of (analytical) method and (constructive) interpretation as far as possible. The comparative approach should be understood and used as a method of comparative analysis in accordance with the standards of religious studies, while theological reflection should constitute the hermeneutical frame of motivation and interpretation.
\end{abstract}

Keywords: Comparative Theology; religious studies; religious truth-claims

\section{Introduction}

In the German-speaking academy there is not only a split but sometimes a harsh sibling rivalry between the disciplines of theology and religious studies. "Comparative Theology" (CTh) falls between the two stools and comes under scrutiny and even suspicion from both sides. In order to understand that tension we need to take a brief look back in the history of the relationship between the siblings.

\section{Sibling Rivalry between Theology and Religious-Studies}

Before religious studies developed as an academic discipline of its own the related questions were dealt with in other departments: in theology (often associated with Old Testament studies or Mission-studies) on the one hand and in ethnology and philology (especially Orientalism) which were 
rooted in the humanities on the other. In Tübingen, for example, the Indologist and Orientalist Rudolf von Roth (1821-1895) regularly lectured on "Allgemeinen und Vergleichenden Religionswissenschaft" ("General and Comparative Studies of Religion”). Friedrich Max Müller can be considered as the very originator of "Comparative Studies of Religions" ("Vergleichende Religionswissenschaft") in the 19th century [1].

A first attempt to integrate the studies of the history of religions into theology (especially in the exegesis of biblical text) was undertaken by the "Religionsgeschichtliche Schule" at the turn from the 19th to the 20th century - which had its center at the theological faculty of Göttingen. The scholars who adhered to that movement analyzed the Bible in the context of studies on the ancient Jewish, Babylonian, Persian and Hellenistic culture and religion. Their motivation for research was a theological one. They strived for a deeper understanding of the emergence and development of the sacred texts of Christianity. Ernst Troeltsch, who was called the "theologist of the Religionsgeschichtlichen Schule" went even further in trying to show on the basis of historical studies that in Christianity the highest values of the history of religions are realized. It was not the least such an apologetic application of religious studies which provoked the emancipation of that discipline from theology.

The company between the uneven siblings parted after World War I. Both turned away from each other. The model of integration was replaced by a model of independence or even dissociation.

On the one hand Karl Barth and the other proponents of the Dialectic-theology movement regarded religious studies as irrelevant for theology. They focussed on the revelation of God in Jesus Christ as it is witnessed in the Bible. Religion was regarded as an epitome of the sinful human and set in strong opposition to faith which is the gift of God alone. As a consequence studies of the history of religion were regarded as research on the historical manifestations of human striving for transcendence and thus to be located in the humanities.

On the other hand scholars of religious studies like Joachim Wach claimed independence for their discipline. In his 1924 published reflections on the epistemological foundations of religious studies [2] he drew a clear and sharp line of demarcation between theology (including the philosophy of religion) and the new discipline which he called with emphasis science of religion ("Religionswissenschaft"). Following Max Weber's ideal of an "empirical science" he stressed the empirical method in studying religious phenomena. "The task of Religionswissenschaft is the exploration and depiction of the empirical religions" [3]. He criticized the "Religionsgeschichtliche Schule" for being centered in Christianity and for pocketing the studies of religious history into theology. In contrast to theology religious studies has to follow a non-confessional agenda, to be ideologically neutral, non-positional and non-normative. It has to keep methodological distance as well to the religious attitudes of the researcher as to the religious phenomena which are the objects of its research. It is obliged to dispense with any value-judgments ("epochè").

In his 1988 published introduction "Was ist Religionswissenschaft?" Hans-Jürgen Greschat—who taught history of religions at the University of Marburg - established a similar borderline between theology and religious studies: While the latter apprehends her objects of study according to their own categories and standards theology applies categories which are coined by the Christian tradition. He stated that if religious studies are conducted by theologians non-Christian phenomena will probably become assimilated to a Christian hermeneutical frame of reference and thus be usurped. The cultural 
turn of religious studies, its methodological paradigm-shift from a phenomenological to a culture-analytic approach has deepened the gap between the siblings.

The more religious studies emancipated from the inclusion into theology and developed as a distinct academic discipline, the more the chairs for religious studies tended to leave the theological faculties and institutionalize itself in the humanities as an own branch of historical and cultural studies. In this process of emancipation it formed its academic self-understanding frequently in a sharp and sometimes even polemical distinction from theology. Theology became regarded as an ideological enterprise which lacks scientific integrity. That argument quite often is used to demand for institutional (including financial) support of religious studies by the universities at the cost of theology.

CTh now seems to be located right in the middle of religious studies and theology and thus gets entangled in their rivalry. It claims to be a theological enterprise which is rooted in religion as opposed to stand beyond and teach about religion. It sticks to the truth-claims of Christian faith and asks-like Ernst Troeltsch did - for the validity of religious ideas and practices, as well as for criteria of judging religious phenomena. Thus it does not strive for religious neutrality [4] but presents itself as a normative approach. It differs from the 'old' CTh (which originated from Schleiermacher and found its fully developed form in Troeltsch) by turning to specific phenomena and does not try to create "ideal-types". Its method is micrologic, not macrologic. It shares that methodological turn with present comparative religious studies ("Vergleichende Religionswissenschaft") which also works on the microlevel, asking from there for functions and structures of religious appearances.

The critical questions from both sides - from the side of religious studies and from the side of theology — are similar to those which were addressed by Ernst Troeltsch and his companions.

\section{Criticism from the Side of Religious Studies}

Scholars of religious studies ask critically: Does CTh 'theologize' the comparative method of religious studies and - as a consequence - lead to a backlash of the emancipation of religious studies from theology in the 20th century? CTh seems to restore the model of integration and to revitalize the agenda of the "Religionsgeschichtliche Schule". The difference to that movement lies in its reference not so much to the history of religions but to its present manifestations. But that makes things even worse in the eyes of the critics.

Jürgen Mohn, who teaches religious studies at the University of Basel, states a clear cut difference between comparative religious studies and CTh. It relates to the truth-question and concerns the method of CTh as he noticed it in the work of James Fredericks [5]. In his comparisons between the notions of "person" in the Buddhist philosophy of Dōgen and in Trinitarian theology [6] Fredericksaccording to Mohn - relates the Buddhist tradition immediately to 'his' Christian tradition and thus enters into a dialogue. As distinct from a dialogue, a comparison (and all the more a methodological testable comparison) needs a third level (tertium comparationis). It needs a perspective which is different from the self-understanding of the traditions and it needs categories which are not interwoven by them. Otherwise one falls back into what Mohn calls a "self-comparison" of the 'own' with the 'other' ("Selbstvergleich mit dem Fremden" [7]), which on the basis of the own religious tradition tries to determine similarities and differences in the other tradition, in order to deepen the understanding of the own tradition. The problem of such a method of relating the 'other' to the 'own' lies in transferring 
tradition-specific concepts like "ontology" or "salvation" to the other tradition to which they do not comply. The result may be a better understanding of the one's tradition but at the cost of possibly misunderstanding the other.

Robert C. Neville and Klaus von Stosch are aware of that jeopardy. Thus von Stosch pleads for introducing the role of a "third" participant in interreligious comparisons ("Instanz des Dritten") [8] and refers to Robert C. Nevilles postulation of a "cloud of witnesses" [9]. It is interesting to compare the suggestions of Mohn, von Stosch, and Neville. While for Mohn the "third" is the acting subject who conducts the comparison, for von Stosch and Neville he/she plays only the role of a critical observant who has to guarantee that the actors who conduct the comparison do not diminish the differences, respect the otherness of phenomena from the other tradition and prevent assimilations. The acting subjects for them are adherents of the respective religious traditions (mostly theologians) while for Mohn it is the "neutral' scholar of religious studies. According to Neville the "cloud of witnesses" consists of the scientific community in the theologies of the religious traditions and in religious studies in the present and the past. Von Stosch assigns the role of the "third" to anyone who is not member of the religious traditions which are to be related to each other. He/she can be an atheist or an agnostic or an adherent of another religion or a scholar of cultural studies. It is crucial that he/she represents another basis idea ("hinreichend verschiedene Grundidee" [10]). For Mohn the "third" is the "first". The "third" is not primarily a personalized but stands for a method. Mohn's reflections on that issue are not located on the level of interreligious communication but are part of a theory of science ("Wissenschaftstheorie") of the religious studies. They refer to the epistemological basis of that discipline and describe the setting of the comparison, the structure of the 'room' in which it takes place. For the comparison it does not need the persons who belong to specific religious traditions but only the scholar of religious studies. The adherents who represent the traditions in their specific way (including the truth-claims of those traditions) are objects of comparison.

The epistemological and methodological difference between comparative religious studies and CTh correlates a different attitude towards the truth-question. While religious studies-according to Mohn - are basically abstinent to religious truth-claims CTh shares the truth-claims of the Christian tradition. The "third" level is truth-laden. Klaus von Stosch does not take truth as something given which is exclusively represented in that tradition. Although it is grounded in God's revelation in Christ Christian faith and theology cannot claim to possess the truth in its plentitude. That is due to the universal und eschatological nature of that truth. It exceeds beyond the Christian tradition and its consummation is yet to come. Thus Christians have to be open for its ongoing self-manifestation which includes other religious traditions as well. Only on this epistemological premise the project of CTh is possible - in contrast to the absolute truth-claims on one side and to abandoning the question of truth on the other. Interreligious encounters are means of discovering that truth.

This avowal to truth not the least is supposed to protect CTh against the charge of relativism as it is raised frequently against the pluralist model of the theology of religions. But what does it mean in the concrete work of CTh? All the case studies I know of do not try to evaluate religious phenomenaneither those of the Christian religion nor those of other religions. They practice a "passing over and coming back" (John S. Dunne) but they do not ask for truth. Does that dissonance between programmatic sketches and the real performance indicate a methodological problem? Some proponents of the CTh offer sets of criteria evaluating religious phenomena [11] but those reflections remain on a 
rather abstract philosophical level. They are not applied to specific interreligious comparisons and probably not easy applicable. If such an application is supposed to be the way of seeking for truth then this does not happen here.

If it would happen the question occurs how to relate CTh to theology of religions. If truth-seeking presupposes that the seekers have a pre-conception ("Vorverständnis") of what they seek so that they can identify truth in what they have found and if that pre-conception is coined by Christian beliefs then an inclusivism in terms of theology of religion is unavoidable.

Concerning the question of truth the positions of the Comparative theologians are not in accord. Keith Ward distinguishes between confessional and comparative theology. Confessional theology is restricted to the Christian tradition, tries to unfold its content in order to foster its reception. It is based on the assumption that this tradition roots in an authentic revelation of God und thus leads into the salvific truth of God. Comparative theology, however, relates the Christian belief to the beliefs and religious practices of other religions. According to Ward CTh is "an intellectual discipline which enquires into ideas of the ultimate reality and goal of human life, as they have been perceived and expressed in a variety of religious traditions" [12]. Its task is to discover similarities and differences between different religious beliefs and practices. The question of truth is not crucial for that endeavor. CTh "does not, as such, and like confessional theology, presuppose the truth of one tradition, and see the others from its own point of view" [13]. It is a method of relating religious phenomena which does not presuppose the claim that the own religions tradition manifests the truth. It abstains from valuejudgments and thus does not need to develop and apply criteria for assessing truth-claims. It is theology inasmuch as it refers to a transcendent reality and not only to empirical religious phenomena, and as much as it refers to the religious traditions as assumed manifestation of that reality.

To describe the task of CTh in that way obviously differs from Clooneys, Fredericks and von Stosch's understanding. The difference may be-at least partly-explainable by taking into account that those three are roman-catholic theologians look for an alternative to the pluralist theology of religions as it was condemned by the "Congregation for the Doctrine of the Faith" (CDF), especially in the declaration "Dominus Iesus" (2000). As many of their colleagues they strive for creating a theological foundation of interreligious dialogue while not arousing suspicion of being a pluralist oreven worse - a relativist. Thus they stress the importance of being loyal to the truth as it is manifest in the Christian tradition but goes beyond. As an Anglican, Ward, however, is free from such considerations. He does not need to attune his theological position with the normative standards of the ecclesiastical magisterium. That is not to say that for the Catholic proponents of CTh there are no other motivations for creating and developing that approach. Clooney, like Ward, points to his biographical experience of religious diversity [14]. Ward felt challenged by that plurality and compelled to answer the question why humans who seek the one truth differ so deeply in their perceptions of it. So he asked: Is there a way of mediating between those differences? [15] For Ward, as for the other Comparative Theologians, to mediate between religious traditions is not primarily a question of theological programs, located in the debate on theology of religions (on that level Ward tends to be a pluralist), but a matter of the credibility and of intellectual integrity of his Christian faith. But it is obvious that especially the Roman-Catholic proponents of CTh try to proof the theological legitimacy of that approach by stressing that it is to be practiced within confessional theology [16], while Ward 
regards CTh as a method which widens the horizon of confessional theology and stands in tension over against it.

\section{Criticism from the Side of Theology}

While the critical questions from the side of the religious studies focus on the "Standortgebundenheit" of CTh, on being tied to the normative position and perspective of Christian belief, the objections from the side of theology appeal to its alleged tendency to dissolve confessional into an interreligious theology. The crucial question here concerns the epistemological basis of Christian belief and theology: Is no longer the Scripture alone (sola scriptura) or the Scripture (as the norma normans) plus the confessions of faith (as the norma normata) and/or (for Roman-Catholic believers) the magisterium the source of belief and theology? Is it also the encounter of religions?

The critics may point to Klaus von Stosch's statement that interreligious dialogue is the basis for CTh [17] - and thus for theology in general, because theology altogether should be done in a comparative way. It is a theology of dialogue. Von Stosch does not intend to create a new theology but to do confessional theology as comparative theology. On the other hand, he stresses that the traditional confessional theologies will undergo transformations. How is that to be understood? Are the non-Christian traditions sources of authentic theological knowledge or are they regarded merely as hermeneutical frames for interpreting the Christian tradition?

More radical is the suggestion of Keith Ward to strive for a "global" theology [18]. For him the whole history of religions constitutes the epistemic source of theology. In that respect his program overlaps with the demand for an interreligious theology as it is raised by some proponents of a 'pluralist theology of religion' like Perry Schmidt-Leukel [19] or Rose Drew who worked with him at Glasgow University [20]. The critics may blame Ward and all those who try to extend the epistemological basis of theology for betraying the revelation in Christ by looking for 'revelations' elsewhere.

Clooney is more cautious inasmuch as his normative point of reference is the revelation in Christ. He does not strive for a global theology but for an "inter-theology", as Norbert Hintersteiner puts it [21]. But even here the question arises: How are the non-Christian traditions - in his case: the Hindu traditions - to be qualified in terms of a theological epistemology? For the "deep learning across religious borders" advocated by Clooney needs a double or multiple religious loyalty on the side of the Comparative Theologian. Is that an asymmetrical loyalty?

This is not the least a dispute on 'apologetics'. Ward regards global theology as an alternative to an 'apologetic' way of doing theology. Other proponents of CTh share that aversion to apologetics. Friedemann Eissler by contrast claims that an apologetic attitude necessarily is tied to holding on to the truth of Christian faith as Francis Clooney, James Fredericks and Klaus von Stosch intend to do. Apologetics should not become discredited as a polemical distortion of other religious beliefs and practices in order to demonstrate the superiority of the Christian religion [22]. Paul Tillich qualified theology as a whole as an apologetic endeavor in the sense of giving answers to the existential questions of the contemporaries.

Eissler insist that there is a qualitative difference between showing respect towards adherents of other religions traditions (and towards the traditions itself) and acknowledging those traditions (including their truth-claims) theologically. He claims to distinguish between successful 
communication and normative relevance. Is it possible-Eissler asks - to turn to another religion on the level of normative relevance without departing from ones one?

A closely related question concerns in regard to witnessing the Christian faith towards people of other (or no) religious faith and thereby touches the issue of 'mission', which was and is a vital manifestation of Christian faith since its very origins. If CTh is not only a subdiscipline of theology but is supposed to become the new paradigm for theology as a whole - as Klaus von Stosch insistsdoesn't that marginalize or even exclude missionary efforts in the sense of inviting communication of Christian faith? What about the claims of universality which are inherent in the gospel of Jesus Christ and which go beyond the Christian language-games? What about the provocation of that message which according to Paul is a stumblingblock unto the Jews, and foolishness unto the Greeks (1Co 1:23)? How in general does the "proprium" (the characteristic, crucial features) of this message, in which it is fundamentally distinguished from other forms of faith, come into play? The more we turn to the core of it the more a comparison becomes difficult because it lacks a tertitum comparationis. It is possible to give witness of such core-beliefs in a dialogical communication-but is it possible (or at least fruitful) to compare them?

\section{CTh as a Bridge between Religious Studies and Theology}

In his "Introduction to the science of religion" Max Müller states that there is "a doctrine more unchristian than any that could be found in the pages of the religious books of antiquity, viz. that all the nations of the earth before the rise of Christianity, were mere outcasts, forsaken and forgotten of their Father in heaven, without a knowledge of God, without a hope of salvation. If a comparative study of the religions of the world produced but this one result, that it drove this godless heresy out of every Christian heart, and made us see again in the whole history of the world the eternal wisdom and love of God towards all His creatures, it would have done a good work." [23]

Müller's statement is as relevant today as it was in 1870, when he gave his lectures on the "Science of Religion" and pleaded for a comparative approach in the study of religion. He hoped that such an approach would overcome the "heresy" of exclusivism. To call exclusivism a heresy means to see it in contradiction to fundamental convictions of Christian faith.

If CTh wants to assert its claim to be a theological enterprise it needs to enroot the comparative approach in a theology of religions which shows that from the very heart of the Christian faith we can expect God's salvific presence to be present not only in the Christian tradition. That creates an attitude of 'theological curiosity' which expects to meet those representations in other forms of faiths. From a Christian perspective they can be identified as such - as formations of grace - in the light of the Christ-revelation. Such a hermeneutical inclusivism cannot be avoided. And it need not be avoided because it has nothing to do with a claim of superiority. The adherents of other religious tradition will use their normative worldviews to decipher manifestations of the transcendent reality in the immanent reality of nature and history. That leads to a mutual hermeneutical inclusivism. The different faith-perspectives can be set in a dialogical relation.

On that hermeneutical basis and in the frame of a theology of religion (which should not become reduced to the debate on the 'models' of exclusivism, inclusivism und pluralism) interreligious comparisons on the micro-level seem possible and useful. The individual and communal 
faith-perspectives on the medium-level cannot be the object of a methodological comparison and the faith traditions as a whole on the macro-level still less.

\section{Conclusions}

I suggest that interreligious comparisons are to be conducted by the standards of religious studies. That is not a theological endeavor in itself. Like historical exegesis of biblical texts it is a method of philological and cultural studies which can and should be applied by theology. Theological reasoning comes into play first, on the level of motivation which precedes the comparison, and second, on the level of interpretation which follows it. Thus theology creates the frame of the comparison but does not interfere with it methodologically. Such a distinction of levels should invalidate criticisms from the side of religious studies and help to defend CTh against becoming charged of reducing theology to cultural studies by abandoning the truth claim of Christian faith. According to that gradation CTh is to be regarded as a method which can be applied to every religion. The method stays the same while the frame can change.

\section{References and Notes}

1. Friedrich M. Müller. Einleitung in die vergleichende Religionswissenschaft, 1st German ed. 1874. Reprint: Saarbrücken: Verlag Classic Edition, 2010.

2. Joachim Wach. Religionswissenschaft. Prolegomena zu ihrer wissenschaftstheoretischen Grundlegung. Leipzig: J. C. Hinrichs'sche Buchhandlung, 1924. See also: Rainer Flasche. Die Religionswissenschaft Joachim Wachs, Berlin: De Gruyter, 1978.

3. Wach, 68 (translation R.B.).

4. Klaus von Stosch. Komparative Theologie als Wegweiser in der Welt der Religionen. Beiträge zur Komparativen Theologie 6. Paderborn et alii: Ferdinand Schönigh, 2012, 231; Cf. Keith Ward. Religion and Revelation. A Theology of Revelation in the World's Religions. Oxford: Clarendon Press, 1994, 40.

5. Jürgen Mohn. "Komparatistik als Position und Gegenstand der Religionswissenschaft." In Komparative Theologie. Interreligiöse Vergleiche als Weg der Religionstheologie, edited by Reinhold Bernhardt and Klaus von Stosch. Beiträge zu einer Theologie der Religionen 7. Zürich: Theologischer Verlag Zürich, 2009, 225-276.

6. James Fredericks. Das Selbst vergessen: Buddhistische Reflexionen zur Trinität. In Komparative Theologie, edited by Reinhold Bernhardt and Klaus von Stosch. 203-223.

7. Mohn, 269.

8. Von Stosch, 208-211.

9. Robert Cummings Neville. Philosophische Grundlagen und Methoden der Komparativen Theologie. In Komparative Theologie, edited by Reinhold Bernhardt and Klaus von Stosch. 42.

10. Von Stosch, 209.

11. Von Stosch, 293-316.

12. Ward. Religion and Revelation, 40.

13 Quoted from the English version of the paper which was published as: Keith Ward. Programm, Perspektiven und Ziele Komparativer Theologie. In Komparative Theologie, edited by Reinhold 
Bernhardt and Klaus von Stosch. 55-68. The German translation reads: „Sie setzt als solche weder die Wahrheit einer Tradition voraus, wie es in der konfessionellen Theologie geschieht, noch betrachtet sie die anderen nur aus der eigenen Perspektive." 63.

14. Francis X. Clooney. Comparative Theology. Deep Learning across Religious Borders. Malden, MA: Wiley-Blackwell, 2010, 1-23.

15. Ward. Programm, 59.

16. Von Stosch, 211f. Clooney, 111ff.

17. Von Stosch, 212.

18. Keith Ward. The Idea of 'God' in Global Theology. In Naming and Thinking God in Europe Today, edited by Norbert Hintersteiner. Amsterdam/New York: Rodopi, 2007, 377-388.

19. Perry Schmidt-Leukel. "Interkulturelle Theologie als interreligiöse Theologie." Evangelische Theologie 1 (2011): 4-15.

20. See her contribution to this issue. See also: José. María Vigil, ed. Toward a Planetary Theology (Along the Many Paths of God V). Montreal: Dunamis Publishers, 2010.

21. See: Norbert Hintersteiner. Interkulturelle Übersetzung in religiöser Mehrsprachigkeit. Reflexionen zu Ort und Ansatz der Komparativen Theologie. In Komparative Theologie, edited by Reinhold Bernhardt and Klaus von Stosch. 114.

22. Friedemann Eißler: "Komparative Theologie. Eine Alternative zu bisherigen religionstheologischen Konzepten?" Zeitschrift für Religions- und Weltanschauungsfragen 12 (2011): 449-455.

23. Friedrich Max Müller. Introduction to the Science of Religion (1870). London: Longmans, Green, and Co., 1882. Reprint: Elibron Classic Replica Edition, Boston: Adamant Media Corporation 2005, 149.

(C) 2012 by the author; licensee MDPI, Basel, Switzerland. This article is an open access article distributed under the terms and conditions of the Creative Commons Attribution license (http://creativecommons.org/licenses/by/3.0/). 